\title{
総合論文*
}

\section{有機化合物の酸化還元反応を用いた極微量金属イオンの 接触分析法}

\author{
中 野 惠 文**
}

\author{
Kinetic-catalytic determinations of metal ions at ultratrace levels by \\ using redox reactions of organic compounds
}

\author{
Shigenori NAKANO** \\ ${ }^{* *}$ Faculty of Education, Tottori University, 101, Minami 4-chome, Koyama-cho, Tottori 680-0945
}

(Received 30 September 1998, Accepted 11 November 1988)

\begin{abstract}
This paper describes highly sensitive and selective catalytic-spectrophotometric methods for the determination of metal ions such as copper(II), cobalt(II), chromium(III), iron(II, III), manganese(II) and vanadium(IV, V). These methods are based on their catalytic effects on the following color-forming reactions: (1) the hydrogen peroxide oxidative coupling of $N$-phenyl-p-phenylenediamine (PPDA) with $N, N$-dimethylaniline (DMA) or m-phenylenediamine; (2) the oxidation of PPDA with hydrogen peroxide; (3) the oxidative coupling of 3-methyl-2-benzothiazolone hydrazone with DMA or $\mathrm{N}$-ethyl- $\mathrm{N}$ (2-hydroxy-3-sulfopropyl)-3,5-dimethoxyaniline in the presence of hydrogen peroxide or dissolved oxygen; and (4) the bromate oxidative coupling of 4-aminoantipyrine with DMA. In order to enhance the catalytic effect of metal ions and improve the sensitivity of the methods, some ligands were used as activators. Furthermore, the addition of surfactants to the reaction systems also increased the sensitivity. The present photometric methods with a batch and/or flow-injection mode allow for the determination of the metal ions in the range $10^{-11} \sim 10^{-7} \mathrm{M}$ with good precision. These methods have been successfully applied to the determination of these ions in real samples.
\end{abstract}

Keywords : catalytic method of analysis; redox reaction; activator; surfactant; determination of metal ions.

\section{1 緒言}

触媒は化学反応の平衡位置を変化させることなく, 反 応の活性化エネルギーの低い別の反応経路を経由するこ とによりその反応の速度を増加させる．この反応速度の

* 中国四国支部創立 40 周年記念

** 鳥取大学教育学部: 680-0945 鳥取県鳥取市湖山町南 4-101
増大を利用して極微量の触媒を定量しょうとする方法が 接触分析である.この分析法の特長は, 触媒が化学量論 的に作用するのではなく, 循環再生して主反応（あるい は指示反応）に関与するので，反応条件を適切に選べ ば，特殊な機器を使用することもなく簡単な操作で高感 度定量が行えることである. 接触分析により到達可能な 触媒の分析濃度は $10^{-16} \mathrm{M}$ とも言われている1).

接触分析においては, 吸光光度法, 蛍光法など各種の 
方法を検出手段として酸化還元反応, 配位子置換反応, 醉素反応などが指示反応として用いられている ${ }^{1) ~ 12) . ~}$ このうち酸化還元反応を用いた吸光度測定による接触分 析法が最も多く, 1876 年アニリンの塩素酸塩による酸 化反応を用いた Vの接触分析が, 最初の報告と言われ ている ${ }^{677)}$. その後, 1934 年に Sandell $ら^{13)} に よ り$ As (III) - Ce(IV) 反応系を用いたヨウ化物イオンの定量が報 告され，現在までに多数の報告がなされている．しか し, 反応速度を追跡する方法であるためバッチ法による 操作では, 反応時間, 反応温度のみならず試薬の添加順 序, 添加時間までも正確に設定する必要があった。

近年, 接触分析がフローインジェクション（FIA）法 に適用されている ${ }^{8) 9}$. FIA 法では流路系の組み方により 試薬の添加順序などを定めることができ, 又反応条件の 制御が極めて容易となり, バッチ法での難点を補ってい る.

著者らは, 酸化反応を指示反応として吸光度測定によ る金属イオンの新しい接触分析法の開発をしてきた. 本 論文では，主に酸化カップリング反応を用いた極微量金 属イオンの接触分析について報告する.

\section{2 接触分析の原理}

\section{$2 \cdot 1 \quad$ 酸化還元反応にお(る接触作用 ${ }^{1) \sim 10}$}

接触分析で用いられている酸化還元反応は熱力学的に は有利な反応であるが，非常に遅い反応である．還元剤 Red と酸化剂 Ox が反応して生成物 $\mathrm{P}$ 及び $\mathrm{Q}$ 生成す る反応 (1) において

$$
\operatorname{Red}+\mathrm{Ox} \rightarrow \mathrm{P}+\mathrm{Q}
$$

触媒としての金属イオン $\mathrm{M}^{(n+1)+}$ が存在すると, 次の反 応が進行し， Pの生成は $\mathrm{M}^{(n+1)+} に よ り$ 促進される.

$$
\operatorname{Red}+\mathrm{M}^{(n+1)+} \rightarrow \mathrm{P}+\mathrm{M}^{n+}
$$

更に反応 ( 2 ）で生成した $\mathrm{M}^{n+}$ が Ox と反応し，

$$
\mathrm{M}^{n+}+\mathrm{Ox} \rightarrow \mathrm{M}^{(n+1)+}+\mathrm{Q}
$$

$\mathrm{M}^{(n+1)+}$ が再生されると, 再び反応 ( 2 ）が進行すること になる，反応系内に金属イオンが $\mathrm{M}^{(n+1)+}$ として常に存 在するためには，

$$
v_{1} \gg v_{2}>v_{3}
$$

となることである。ここで， $v_{1}, v_{2}$ 及び $v_{3}$ はそれぞれ 反応 (1)，（2）及び（3）の反応速度である.

このような反応で触媒として作用するのは異なった酸 化数を持つイオン，すなわち, $\mathrm{Cu}(\mathrm{II}), \mathrm{Co}(\mathrm{II}), \mathrm{Fe}(\mathrm{II}$, III), Mn(II) などである. Red として用いられるのは一 般に有機化合物が多く, Ox としては過酸化水素, 溶存 酸素, 臭素酸塩, 過ヨウ素酸塩などが使用されている. これらの Ox は高い酸化還元電位を有し, 有機化合物を 酸化できるもののその速度は遅く, $\mathrm{M}^{n+}$ から $\mathrm{M}^{(n+1)+}$ へ の酸化を速やかに行うことができる.

触媒 $\mathrm{M}^{(n+1)+}$ が共存する反応系での反応速度は, 一般 に次のように表される。

$$
\begin{aligned}
& -\mathrm{d}[\operatorname{Red}] / \mathrm{d} t=\mathrm{d}[\mathrm{P}] / \mathrm{d} t= \\
& \quad k_{i}[\operatorname{Red}][\mathrm{Ox}]+k_{c}[\operatorname{Red}][\mathrm{Ox}]\left[\mathrm{M}^{(n+1)+}\right]
\end{aligned}
$$

ここで， $k_{i}$ 及び $k_{c}$ は，それぞれ反応 $(1)$ 及び（2）の 速度定数である. 式 (4) の条件下で Red の減少速度あ るいは $\mathrm{P}$ の増加速度を測定することにより $\mathrm{M}^{(n+1)+}$ の濃 度を求めることができる，又，速やかに酸化される $\mathrm{M}^{n+} も \mathrm{M}^{(n+1)+}$ と同様に分析できる. 式 (5) の第 1 項 は非接触反応の速度でいわゆる試薬空試験值であり, 第 2 項は接触反応の速度である. 第 1 項に比べ第 2 項が十 分大きい条件を設定できれば，高感度で再現性の良い分 析法が得られる.

Red あるいは P の変化量, 例えば吸光度変化を追跡 して反応速度が測定される際には次の方法が用いられ $ろ^{6) 77}$. (1) 反応物あるいは生成物の吸光度一時間曲線か ら速度を求める（初速度法, Tangent 法), (2) 一定時 間後の吸光度を測定する (定時間法), (3) 一定の吸光 度に達する時間を測定する (時間測定法)，(4) 接触反 応における誘導期間を測定する.

本論文で扱うバッチ法では, 測定が簡便な定時間法を 用いた。, 又, 普通の FIA 法では, 試薬溶液などを一定 の流量で送液して一定の長さのコイル内で反応させた 後, 吸光度を測定することになるので定時間法というこ とになる。なお，FIA 法ではバッチ法に比べて反応時間 が短く (2〜3 分), 高感度を得るための方策が必要とな る.

\section{$2 \cdot 2$ 錯形成剤による活性化効果}

金属イオンが関与する接触反応系において，ある種の 配位子の存在により接触反応の速度が著しく増大するこ とがある。このような作用を示す配位子は活性化剤 (activator) と呼ばれ, 接触分析の感度を飛躍的に高め 


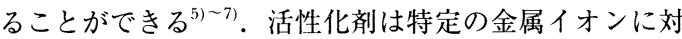
して有効に作用するので，分析感度の上昇が図れるとと もに選択性の向上にもつながる.

これまで著者らが報告した接触分析において用いた活 性化剂を Table 1 に示す. Cu(II) の接触分析における アンモニア，ピリジン (py), Fe(II, III) の分析法におけ る 1,10-フェナントロリン'(phen), 2,2'-ビピリジン (bpy)，Co(II) における 1,2-ジヒドロキシ-3,5-ジスルホ ン酸（Tiron），V(IV, V) における Tiron， Cr(III) におけ る EDTA などが極めて有効に作用する. 又, $\mathrm{Mn}(\mathrm{II})$ の 分析における Tiron とトリエチレンテトラミン（Trien） のように二つの活性化剂を同時に使用することにより感 度が向上する反応系もある（Table 1）。これらの活性 化剂は金属イオンと錯形成することにより金属の有効電 荷を増大させ，その効果が基質分子内での結合の切断を 容易にするか，反応系の電位変化及び金属－活性化錯体 の構造変化などによって触媒の再生反応が容易に起こる
などの考えがあるが2)58899，詳細な点は明らかではない. なお，活性化剂によっては，その濃度が高くなると逆に 阻害剂として作用することがある。これは活性化剂一金 属-基質の三元錯体の形成により反応が進行している場 合に見られる特徵である ${ }^{2)}$.

\section{$2 \cdot 3$ 界面活性凧}

化学量論的反応に基づく分析法において，界面活性剤 の利用はその感度の向上が認められているが，接触反応 系においてもミセルなどの分子集合体を共存させること により，感度及び選択性の改善を図ることができる。こ れは，次のようなミセルの作用を単独あるいは同時に利 用することによる ${ }^{40) 41)}$.(1) 反応に関与する物質とミセ ルとの相互作用により反応物質がミセル界面に濃縮され る，（2）指示反応がミセル相内で濃縮された状態で起 こる，(3）反応を追跡する指示物質とミセルとの相互 作用によりその物質の安定性が保たれ，又その特性が変

Table 1 Activators used in catalytic reactions

\begin{tabular}{|c|c|c|c|}
\hline Activator & Catalyst & Indicator reaction & Ref. \\
\hline \multirow[t]{4}{*}{ Acetate } & $\mathrm{Cu}(\mathrm{II})$ & $\mathrm{HBS}+\mathrm{PDA}+\mathrm{H}_{2} \mathrm{O}_{2}$ & 14) \\
\hline & $\mathrm{Fe}(\mathrm{II}, \mathrm{III})$ & $\mathrm{PPDA}+\mathrm{DMA}+\mathrm{H}_{2} \mathrm{O}_{2}$ & 15) \\
\hline & & $\mathrm{PPDA}+\mathrm{PDA}+\mathrm{H}_{2} \mathrm{O}_{2}$ & 16) \\
\hline & & $\mathrm{AA}+\mathrm{DMA}+\mathrm{H}_{2} \mathrm{O}_{2}$ & 17) \\
\hline \multirow[t]{3}{*}{ Tiron } & $\mathrm{Co}(\mathrm{II})$ & $\mathrm{PPDA}+\mathrm{H}_{2} \mathrm{O}_{2}$ & 18) \\
\hline & $\mathrm{Ni}(\mathrm{II})$ & $\mathrm{PPDA}+\mathrm{H}_{2} \mathrm{O}_{2}$ & 19) \\
\hline & $\mathrm{V}(\mathrm{IV}, \mathrm{V})$ & $\mathrm{AA}+\mathrm{DMA}+\mathrm{BrO}_{3}^{-}$ & 20) \\
\hline Tiron $+\mathrm{HCO}_{3}{ }^{-}$ & $\mathrm{Co}(\mathrm{II})$ & $\mathrm{MBTH}+\mathrm{DMA}+\mathrm{H}_{2} \mathrm{O}_{2}$ & 21) \\
\hline Tiron + Trien & $\operatorname{Mn}(\mathrm{II})$ & $\mathrm{DPD}+\mathrm{PDA}+\mathrm{H}_{2} \mathrm{O}_{2}$ & 22) \\
\hline Tiron $+1,10$-Phenanthroline & $\operatorname{Mn}(\mathrm{II})$ & $\mathrm{PPDA}+\mathrm{H}_{2} \mathrm{O}_{2}$ & 23) \\
\hline \multirow[t]{2}{*}{ Tartrate } & $\mathrm{V}(\mathrm{IV}, \mathrm{V})$ & $\mathrm{HBS}+\mathrm{PDA}+\mathrm{BrO}_{3}^{-}$ & 24) \\
\hline & & $\mathrm{PPDA}+\mathrm{DMA}+\mathrm{BrO}_{3}{ }^{-}$ & 25) \\
\hline 5-Sulfosalicylic acid & $\mathrm{V}(\mathrm{IV}, \mathrm{V})$ & $\mathrm{AA}+\mathrm{DMA}+\mathrm{BrO}_{3}^{-}$ & 26), 27) \\
\hline EDTA & $\mathrm{Cr}(\mathrm{III})$ & $\mathrm{MBTH}+\mathrm{DMA}+\mathrm{H}_{2} \mathrm{O}_{2}$ & 28) \\
\hline \multirow[t]{4}{*}{ Ammonia } & $\mathrm{Cu}(\mathrm{II})$ & $p$-Anisidine $+\mathrm{DMA}+\mathrm{H}_{2} \mathrm{O}_{2}$ & 29) \\
\hline & & $\mathrm{DPD}+\mathrm{DMA}+\mathrm{H}_{2} \mathrm{O}_{2}$ & $30), 31)$ \\
\hline & & $\mathrm{MBTH}+\mathrm{DMA}+\mathrm{H}_{2} \mathrm{O}_{2}$ & 32) \\
\hline & & $\mathrm{PPDA}+\mathrm{DMA}+\mathrm{H}_{2} \mathrm{O}_{2}$ & 33) \\
\hline Ammonia + Pyridine & $\mathrm{Cu}(\mathrm{II})$ & $\mathrm{PPDA}+\mathrm{PDA}+\mathrm{H}_{2} \mathrm{O}_{2}$ & 34) \\
\hline Pyridine & $\mathrm{Cu}(\mathrm{II})$ & $\mathrm{MBTH}+\mathrm{DAOS}+\mathrm{H}_{2} \mathrm{O}_{2}$ & $35)$ \\
\hline \multirow[t]{2}{*}{ 2,2'-Bipyridine } & $\mathrm{Cu}(\mathrm{II})$ & $\mathrm{MBTH}+\mathrm{DMA}+\mathrm{H}_{2} \mathrm{O}_{2}$ & 36) \\
\hline & $\operatorname{Mn}(\mathrm{II})$ & $\mathrm{MBTH}+\mathrm{DMA}+\mathrm{O}_{2}$ & 37) \\
\hline \multirow[t]{3}{*}{ 1,10-Phenanthroline } & $\mathrm{Cu}(\mathrm{II})$ & $\mathrm{MBTH}+\mathrm{DMA}+\mathrm{H}_{2} \mathrm{O}_{2}$ & $36)$ \\
\hline & $\mathrm{Fe}(\mathrm{II}, \mathrm{III})$ & $p$-Anisidine $+\mathrm{DMA}+\mathrm{H}_{2} \mathrm{O}_{2}$ & 38) \\
\hline & $\operatorname{Mn}(\mathrm{II})$ & $\mathrm{MBTH}+\mathrm{DMA}+\mathrm{O}_{2}$ & 37) \\
\hline 1,10-Phenanthroline + Citrate & $\operatorname{Mn}(\mathrm{II})$ & $\mathrm{MBTH}+\mathrm{DMA}+\mathrm{H}_{2} \mathrm{O}_{2}$ & 39) \\
\hline
\end{tabular}

Tiron: 1,2-dihydroxybenzene-3,5-disulfonate; Trien: triethylenetetramine; HBS: $p$-hydrazinobenzenesulfonic acid; PPDA: $N$-phenyl- $p$-phenylenediamine; DMA: $N, N$-dimethylaniline; PDA: $m$-phenylenediamine; AA: 4aminoantipyrine; DPD: $N, N$-dimethyl- $p$-phenylenediamine; MBTH: 3-methyl-2-benzothiazolinone hydrazone; DAOS: $N$-ethyl- $N$-(2-hydroxy-3-sulfopropyl)-3,5-dimethoxyaniline 
化する.

ビンドシェドラースグリーンの生成反応, すなわち過 酸化水素の存在下での $N, N$-ジメチル-p-フェニレンジア ミン（DPD）と $N, N$-ジメチルアニリン（DMA）との反 応における $\mathrm{Cu}(\mathrm{II})$ の接触作用 ${ }^{30}$ に対して, PerezBendito ら ${ }^{42}$ は各種の界面活性剤の影響を検討した。 そ の中で，ドデシルトリメチルアンモニウムブロミド及び ドデシル硫酸ナトリウム（SDS）が有効な界面活性㓮で あることを見いだし，分析法の改善を図っている。この 系では界面活性剂を添加すると，添加しない場合に比べ 感度が約 4 倍上昇している。

$3 N$-フェニル- $p$-フェニレンジアミンを基質とし た酸化反応を用いる鉄 (II, III)，銅 (II)，コバ ルト（II）及びマンガン（II）の分析

$p$-フェニレンジアミンは酸化剤の共存で, アニリンあ るいはフェノールとカップリングして色素を生成するの で，これらの化合物の検出や比色定量に用いられてい $る^{43)} \cdot N-$ フェニル-p-フェニレンジアミン（PPDA）を分 析試薬として用いた例は見当たらないが，PPDAも又酸 化剤の存在下で, DMA， $m$-フェニレンジアミン（PDA） などとカップリングして色素を生成する.

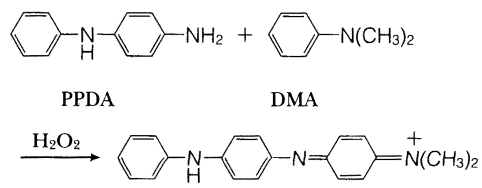

Green compound $\left(\lambda_{\max }=728 \mathrm{~nm}\right)$

過酸化水素の共存下, PPDA-DMA あるいは PPDAPDAの反応において $\mathrm{Cu}$ (II) 及び Fe(II, III) が, 又 PPDA の過酸化水素による酸化反応において Co(II) 及 び Mn (II) が接触作用を示したので，これらの反応系を 用い金属イオンの接触分析を開発した.

\section{$3 \cdot 1 \mathrm{Fe}(\mathrm{II}, \mathrm{III})$ の分析法}

$3 \cdot 1 \cdot 1$ バッチ法 ${ }^{15)} \mathrm{Fe}(\mathrm{III})$ は PPDA-DMA- $\mathrm{H}_{2} \mathrm{O}_{2}$ の反応において $\mathrm{pH} 5$ 付近で接触作用を示し, 酢酸塩が 活性化剂として作用した。この反応系において $\mathrm{Cu}(\mathrm{II})$ も接触作用を示したので，そのマスキング剂として Trien を用いて Fe(II, III) の定量について検討し, 次の ような試薬濃度とした。 $C_{\mathrm{PPDA}}=4.0 \times 10^{-5} \mathrm{M}, C_{\mathrm{DMA}}=$ $1.6 \times 10^{-3} \mathrm{M}, \quad C_{\mathrm{H}_{2} \mathrm{O}_{2}}=2.0 \times 10^{-2} \mathrm{M}, C_{\mathrm{CH} \text { cOOONa }}=0.16 \mathrm{M}$, $C_{\text {Trien }}=2.0 \times 10^{-5} \mathrm{M}$.
この条件下で $\mathrm{pH} 4.8 \sim 5.0$, 反応温度 $40^{\circ} \mathrm{C}$ で反応さ せ, 15 分間後の反応生成物の吸光度 $(728 \mathrm{~nm})$ を測定 した。この操作により作成した $\mathrm{Fe}(\mathrm{III})$ の検量線は，0.6 $\sim 6 \mathrm{ng} \mathrm{ml}^{-1}$ の範囲でBeerの法則に従った. 又, $\mathrm{Fe}$ (II) の検量線は, $\mathrm{Fe}(\mathrm{III})$ の検量線と誤差の範囲内で一 致し, 過酸化水素が $\mathrm{Fe}(\mathrm{II})$ を $\mathrm{Fe}(\mathrm{III})$ に酸化し指示反応 に関与することが示された。従って，本法は試料中の $\mathrm{Fe}(\mathrm{II})$ と $\mathrm{Fe}(\mathrm{III})$ の合量を定量することになる. $4 \mathrm{ng}$ $\mathrm{ml}^{-1}$ の $\mathrm{Fe}(\mathrm{III})$ を分析した際の相対標準偏差 (RSD) は, 2.6\%（ $n=5 ）$ であった。この方法において $\mathrm{Cu}(\mathrm{II})$ は $\mathrm{Fe}$ の定量に対して正の誤差を与えたが, Trienの添加に より $200 \mathrm{ng} \mathrm{ml}^{-1}$ 以下の $\mathrm{Cu}(\mathrm{II})$ の妨害を除くことがで きた. 水道水, 河川水及び海水中の $\mathrm{Fe}$ の定量に応用し た.

$3 \cdot 1 \cdot 2$ FIA 法 $^{16)}$ DMA は水に比較的難溶なので, その代わりに PDAを使用し, FIA 法による Fe(II, III) の接触分析を検討した。バッチ法により得られた結果を 基に, この反応系でも活性化剂として酢酸塩, $\mathrm{Cu}(\mathrm{II})$ のマスキング棛としてTrien を用いた，又，界面活性剤 の検討を行い，その中で Tween 80 を選んだ. Fig. 1 に 示すフローシステムにおいて R1よりキャリヤー溶液, R2 より過酸化水素水, R3 より PPDA 及び Tween 80 の 混合溶液, R4より酢酸アンモニウム及び Trien の混合 溶液が送液され, 試料溶液はキャリヤー溶液の流れに注 入される. 反応コイル内で反応が進行するので，下流に 設けてある検出器により反応生成物の吸光度 $(620 \mathrm{~nm})$ 変化が追跡される. Table 2 に陽イオン性及び非イオン 性の界面活性剤の影響を, 又 Tween 80 を添加した場合

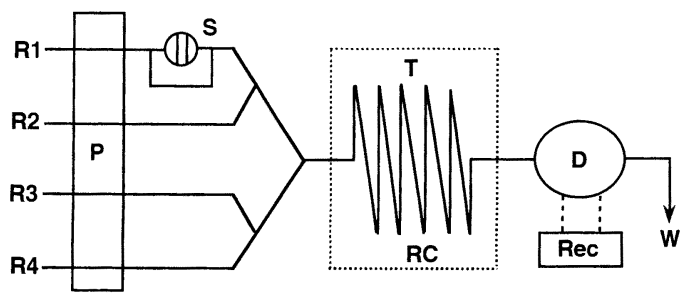

Fig. 1 Flow system for the determination of Fe (II, III)

$\mathrm{R} 1$ : carrier $(0.1 \mathrm{M} \mathrm{HCl})$; $\mathrm{R} 2: \mathrm{H}_{2} \mathrm{O}_{2}(0.4 \mathrm{M})$; R3: PPDA $\left(2.0 \times 10^{-3} \mathrm{M}\right)+$ Tween $80(0.2 \% \mathrm{w} / \mathrm{v}) ; \mathrm{R} 4$ : $\mathrm{CH}_{3} \mathrm{COONH}_{4}(0.5 \mathrm{M})+$ Trien $\left(1.2 \times 10^{-4} \mathrm{M}\right) ; \mathrm{P}$ : micropump $\left(0.8 \mathrm{ml} \mathrm{min}^{-1}\right) ; \mathrm{S}$ : sample injector valve $(180 \mu \mathrm{l})$; RC: reaction coil $(5 \mathrm{~m})$; $\mathrm{T}$ : thermostated bath $\left(55^{\circ} \mathrm{C}\right)$; D: detector $(620 \mathrm{~nm})$; Rec: recorder; $\mathrm{W}$ : waste 
としない場合のフローシグナルを Fig. 2 に示す. Table 2 から明らかなように界面活性剤の存在により感度の増 大が認められ, シグナルもシャープとなることが分かる (Fig. 2). 得られた分析条件（Fig. 1）に基づき作成し た $\mathrm{Fe}$ (III) の検量線は $0.5 \sim 30 \mathrm{ng} \mathrm{ml}^{-1}$ の範囲で直線性 を示し, $\mathrm{Fe}(\mathrm{II})$ の検量線も $\mathrm{Fe}(\mathrm{III})$ のそれと実験誤差の 範囲で一致した。 RSD は $2.6 \% \quad\left(n=10, C_{\mathrm{Fe}(\mathrm{III})}=5 \mathrm{ng}\right.$ $\left.\mathrm{ml}^{-1}\right)$ で, 分析速度は約 30 試料/時であった. $\mathrm{Cu}(\mathrm{II})$

Table 2 Effect of surfactants on the Fe(III)-catalyzed reaction of PPDA with PDA

\begin{tabular}{|c|c|c|}
\hline Surfactant & $\begin{array}{l}\mathrm{CMC}^{\mathrm{c}) 40)} / \\
10^{-3} \mathrm{M}\end{array}$ & $\begin{array}{l}\text { Relative } \\
\text { peak height }\end{array}$ \\
\hline None & - & 10 \\
\hline $\begin{array}{l}\text { Decyltrimethyl- } \\
\text { ammonium bromide }^{\text {a) }}\end{array}$ & 65 & 12 \\
\hline $\begin{array}{l}\text { Dodecyltrimethyl- } \\
\text { ammonium bromide }^{\text {a) }}\end{array}$ & 16 & 18 \\
\hline $\begin{array}{l}\text { Tetradecyltrimethyl- } \\
\text { ammonium bromide }^{\text {a) }}\end{array}$ & 3.5 & 23 \\
\hline Zephiramine $^{\text {a) }}$ & 0.37 & 22 \\
\hline $\begin{array}{l}\text { Hexadecyltrimethyl- } \\
\text { ammonium bromide }^{\text {a) }}\end{array}$ & 0.9 & 23 \\
\hline $\begin{array}{l}\text { Hexadecylpyridinium } \\
\text { chloride }^{\text {a) }}\end{array}$ & 0.92 & 22 \\
\hline Brij- $35^{\text {b) }}$ & $0.034 \sim 0.083$ & 23 \\
\hline Triton $\mathrm{X}-100^{\mathrm{b})}$ & 0.32 & 24 \\
\hline Tween $20^{\text {b) }}$ & $2.7 \sim 3.2$ & 19 \\
\hline Tween $80^{\mathrm{b})}$ & $0.9 \sim 1.1$ & 24 \\
\hline
\end{tabular}

a) $5.0 \times 10^{-2} \mathrm{M}$; b) $0.2 \mathrm{w} / \mathrm{v} \%$; c) Critical micelle concentration. $C_{\mathrm{Fe}(\mathrm{III})}=10 \mathrm{ng} \mathrm{ml}^{-1}$. Conditions as in Fig. 1 except for surfactant concentration.
の妨害はTrien の添加により 20 倍量まで許容でき, 又 Sn(II, IV) を除く他の金属イオンは 20 倍量の共存でも 妨害しなかった．負の誤差を与えた Sn(II, IV) は 10 倍 量で影響を与えなかった. 本法を河川水, 湖沼水及び海 水中の $\mathrm{Fe}$ の定量に応用し, 検量線法, 標準添加法によ り得られた値は互いに良く一致した。

\section{$3 \cdot 2 \mathrm{Cu}(\mathrm{II})$ の分析法}

3・2・1 バッチ法 ${ }^{33)}$ PPDA-DMA- $\mathrm{H}_{2} \mathrm{O}_{2}$ の反応系に おいて, $\mathrm{Cu}(\mathrm{II})$ \& $\mathrm{pH} 5$ 付近でこの反応を著しく促進し たので酢酸を緩衝剤として用い, 又接触反応速度を増大 したアンモニアを活性化剂として共存させた．Fe(III) のマスキング剂としてフッ化物イオンを添加し, Cu(II) の分析条件を検討した。 その結果, $C_{\mathrm{PPDA}}=5.0 \times 10^{-5}$ $\mathrm{M}, C_{\mathrm{DMA}}=1.6 \times 10^{-3} \mathrm{M}, C_{\mathrm{H}_{2} \mathrm{O}_{2}}=6.0 \times 10^{-2} \mathrm{M}$, $C_{\mathrm{CH}_{3} \mathrm{COOH}}=2.0 \times 10^{-2} \mathrm{M}, C_{\mathrm{NH}_{s}}=0.1 \mathrm{M}, C_{\mathrm{F}^{-}}=3.2 \times 10^{-2}$ $\mathrm{M}$ で, 反応 $\mathrm{pH} 5.0 \sim 5.2$, 反応温度 $45^{\circ} \mathrm{C}$ で反応させて 15 分間後の反応生成物の吸光度 $(728 \mathrm{~nm})$ を測定した. この方法により $0.4 〜 4.0 \mathrm{ng} \mathrm{ml}^{-1}$ の Cu(II) が定量可能 となった，検量線はわずかに湾曲したが，RSD は $2.5 \%$ $\left(n=5, C_{\mathrm{Cu}(\mathrm{II})}=1.0 \mathrm{ng} \mathrm{ml}^{-1}\right)$ で再現性も良好であった. この反応系でも触媒となる $\mathrm{Fe}(\mathrm{III})$ はフッ化物イオンの 添加により $200 \mathrm{ng} \mathrm{ml}^{-1}$ まで許容できた. 本法により水 道水 $\left(1.2 \mathrm{ng} \mathrm{ml}^{-1}\right)$ 及び河川水 $\left(0.5 \sim 0.8 \mathrm{ng} \mathrm{ml}^{-1}\right)$ 中 の $\mathrm{Cu}$ を精度良く分析できた.

$\mathbf{3 \cdot 2 \cdot 2}$ FIA 法 $^{34)}$ PPDA-PDA- $\mathrm{H}_{2} \mathrm{O}_{2}$ の反応系を用い $\mathrm{Cu}(\mathrm{II})$ の接触-FIA 法も検討した. この反応系において は二つの活性化剂, すなわちアンモニアと pyを存在さ せた. Fig. 3 に示したように py 濃度の増加とともにピ

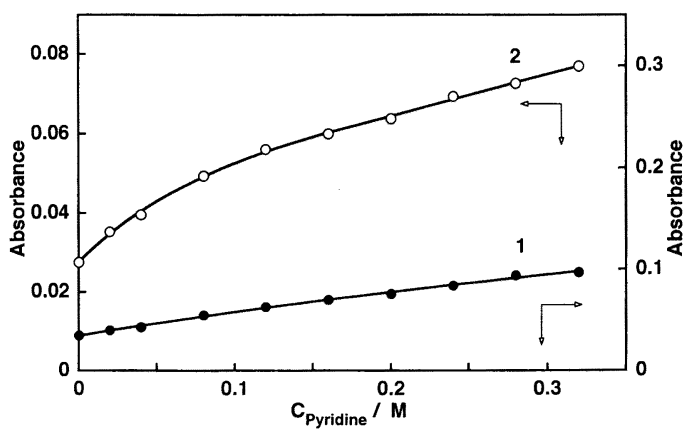

Fig. 3 Effect of pyridine concentration on the uncatalyzed (1) and catalyzed (2) reactions of PPDA with PDA in the presence of hydrogen peroxide $C_{\mathrm{Cu}(\mathrm{II})}, 2.0 \mathrm{ng} \mathrm{ml}^{-1}$. Conditions as in the text. ence (B) of Tween 80 $C_{\mathrm{Fe}(\mathrm{III})}, 10 \mathrm{ng} \mathrm{ml}^{-1}$. Conditions as in Fig. 1. 
一ク高さは増加する. 又, アンモニア濃度の影響も py と同じ傾向であった．界面活性剤として Tween 80 を， $\mathrm{Fe}(\mathrm{III})$ のマスキング剂としてクエン酸を用いた。なお， フローシステムは Fig. 1 に示したものと同様に 4 流路 系とした， R1 よりキャリアー溶液， R2 より過酸化水素 水 $(0.5 \mathrm{M})$, R3 より Tween $80(0.5 \% \mathrm{w} / \mathrm{v})$ を含む PPDA 溶液 $\left(1.0 \times 10^{-3} \mathrm{M}\right)$ が， R4よりアンモニア $(0.5 \mathrm{M})$, py $(0.2 \mathrm{M})$ 及びクエン酸 $\left(2.0 \times 10^{-3} \mathrm{M}\right)$ の

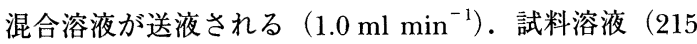
$\mu \mathrm{l} ）$ がキャリヤー溶液の流れに注入され，反応 $\mathrm{pH} 4.6$ $\sim 4.7$, 反応温度 $55^{\circ} \mathrm{C}$ で, $8 \mathrm{~m}$ の反応コイル中で反応を 進行させ, 吸光度 $(620 \mathrm{~nm})$ が追跡される. 本法によ り $0.1 \sim 2.0 \mathrm{ng} \mathrm{ml}^{-1}$ の $\mathrm{Cu}(\mathrm{II})$ が定量可能で, RSD は $2.4 \%\left(n=10, C_{\mathrm{Cu}(\mathrm{II})}=1.0 \mathrm{ng} \mathrm{ml}^{-1}\right)$ で，サンプリング 速度は 30 試料/時であった。共存イオンの影響を検討 したところ, $\mathrm{Cr}(\mathrm{VI})$ を除く金属イオンは 100 倍量まで 許容できた. $\mathrm{Cr}(\mathrm{VI})$ は酸化作用のため正の誤差を与え たが，10倍量では妨害しなかった。この方法により河 川水，湖沼水及び海水中の $\mathrm{Cu}$ を分析した。検量線法及 び標準添加法による分析値は互いに一致した。

\section{$3 \cdot 3$ コバルト(II) の分析法 ${ }^{18}$}

PPDA は, pH 11 付近で過酸化水素により黄色化合物 に酸化される.この反応は微量の $\mathrm{Co}(\mathrm{II})$ により接触的 に促進され，又この反応系に Tiron を添加すると，こ の接触反応速度は著しく増大した．更に, $\mathrm{pH} 11$ 付近で 生成した黄色化合物は酸性溶液（pH 0.5）中では黄色化 合物よりも吸光度の高い青色化合物 $\left(\lambda_{\text {max }}=745 \mathrm{~nm}\right)$ に変化したので，この反応を使えば，Co(II) の高感度 定量が可能となる. しかし，この方法をバッチ法で行う と反応 $\mathrm{pH}$ と吸光度測定の $\mathrm{pH}$ が異なることから操作が 煩雑となるので, FIA 法により検討した.

Fig. 4 に示すシステムにおいて試料溶液は, PPDA 及 びTironの混合溶液（R1）の流れに注入される。この 流れは, 水酸化ナトリウム及び過酸化水素水と混合され

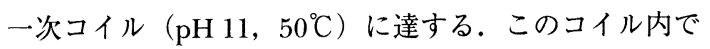
黄色化合物の生成が促進され, 塩酸の添加により青色化 合物に変化する（二次コイル）ので, その吸光度（745 $\mathrm{nm}$ ）変化が追跡される.

Fig. 5 に Tiron 濃度の影響を示す. 濃度の増加ととも にピーク高さは高くなり，Tiron が活性化効果を示して いるが, ある濃度以上になると阻害剤として作用してい ることが分かる.

この方法では記録計のレンジを切り換えることにより $2.5 \mathrm{ng} \mathrm{ml}^{-1}$ の濃度まで検量線を作成できた。 RSD は
$3.2 \%\left(n=10, C_{\mathrm{Co}(\mathrm{II})}=0.08 \mathrm{ng} \mathrm{ml}^{-1}\right)$ となり, 1 時間当 たり約 20 試料が分析可能となった。 $40 \%$ までの $\mathrm{NaCl}$ は妨害を示さず, $100 \mathrm{ng} \mathrm{ml}^{-1}$ の $\mathrm{Cr}(\mathrm{VI}), \mathrm{Mn}(\mathrm{II}), \mathrm{F}^{-}$が $10 \%$ 程度の誤差を与えた。この方法により海水中の Co の定量に応用した。

なお，PPDAの過酸化水素による酸化反応は, $\mathrm{Ni}(\mathrm{II})$ によっても促進され，又 Tironはこの接触反応に対し て活性化効果を示した ${ }^{19)}$ 。そこで $\mathrm{Co}(\mathrm{II})$ の場合と同様 な手法で Ni(II) の FIA 法を検討したところ，0.4〜2.0 $\mathrm{ng} \mathrm{ml}^{-1} \mathrm{Ni}(\mathrm{II})$ の定量が可能となった. しかし, Co(II) の妨害が著しかったので分離操作が必要であった.

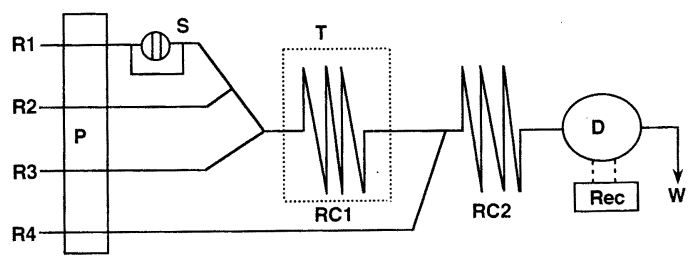

Fig. 4 Flow system for the determination of Co(II) R1: PPDA $\left(6.3 \times 10^{-3} \mathrm{M}\right)+$ Tiron $\left(2.5 \times 10^{-3} \mathrm{M}\right)$; R2: $\mathrm{NaOH}(0.13 \mathrm{M})$; R3: $\mathrm{H}_{2} \mathrm{O}_{2}\left(3.6 \times 10^{-2} \mathrm{M}\right)$; R4: $\mathrm{HCl}$ (3 M); P: micropump (1.5 $\left.\mathrm{ml} \mathrm{min}^{-1}\right)$; $\mathrm{S}$ : sample injector valve $(187 \mu \mathrm{l})$; RC1: primary reaction coil $(1.5 \mathrm{~m})$; RC2: secondary reaction coil $(3 \mathrm{~m})$; $\mathrm{T}$ : thermostated bath $\left(50^{\circ} \mathrm{C}\right)$; D: detector $(745 \mathrm{~nm})$; Rec: recorder; $W$ : waste

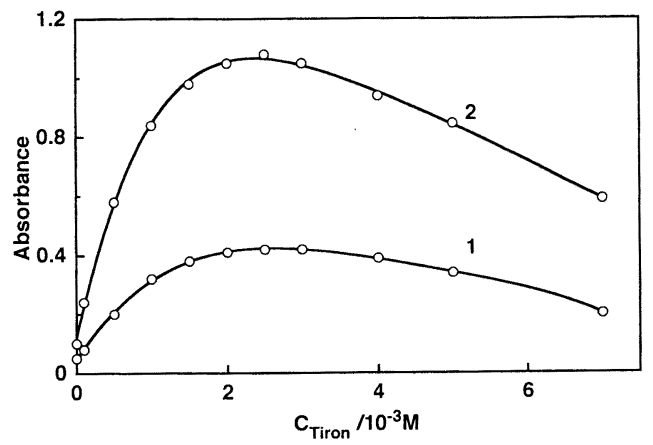

Fig. 5 Effect of Tiron concentration on the Co(II)catalyzed reaction of PPDA with hydrogen peroxide Conditions as in Fig. 4 except for Tiron concentration

$C_{\mathrm{Co}(\mathrm{II})} / \mathrm{ng} \mathrm{ml}^{-1}:(1), 1.0 ;(2), 2.5$ 


\section{$3 \cdot 4$ マンガン(II) の分析 $^{23)}$}

過酸化水素によるPPDAの酸化反応において, Mn (II) も Co(II) と同様に $\mathrm{pH} 11$ 付近においてその接触作 用が認められたので， $N$-シクロヘキシル-3-アミノプロ パンスルホン酸（CAPS）を緩衝剤として用いた。 又， Tiron と phenの二つの錯形成剂の添加により接触反応 速度が増加した. $\mathrm{Co}(\mathrm{II})$ の分析法では, 二次コイル内 を単に酸性にするだけであったが，Mn(II) の場合は， 一次コイル内で接触反応を進行させた後, 硫酸酸性の PPDA 溶液を送液してょり吸光度の高い青緑色化合物 $\left(\lambda_{\max }=775 \mathrm{~nm}\right)$ を生成させ（二次コイル），その吸光 度を追跡することにした，そこで，5流路系のフローシ ステムを組み立て (Fig. 6), Tween 80 の存在下で Mn (II) の分析法を検討した. その結果, Fig. 6 に示す分析 条件を得た。

この方法による $\mathrm{Mn}(\mathrm{II})$ の検量線は, $0.25 \sim 5.0 \mathrm{ng}$ $\mathrm{ml}^{-1}$ の範囲で直線性を示し, 検出限界 $(S / N=3)$ は $0.06 \mathrm{ng} \mathrm{ml}^{-1}$ であった. RSD は $2.8 \%\left(n=10, C_{\mathrm{Mn}(\mathrm{II})}=\right.$ $\left.2.0 \mathrm{ng} \mathrm{ml}^{-1}\right)$ となり， 1 時間当たり約 30 試料の分析が 可能であった. $\mathrm{Cr}(\mathrm{III}, \mathrm{VI}), \mathrm{Fe}(\mathrm{II}, \mathrm{III})$ 及び $\mathrm{Co}(\mathrm{II})$ を除 くイオンは 25 倍量で妨害しなかったが, Cr(III, VI), $\mathrm{Fe}(\mathrm{II}, \mathrm{III})$ は 5 倍量, Co(II) は 2.5 倍量まで許容できた.

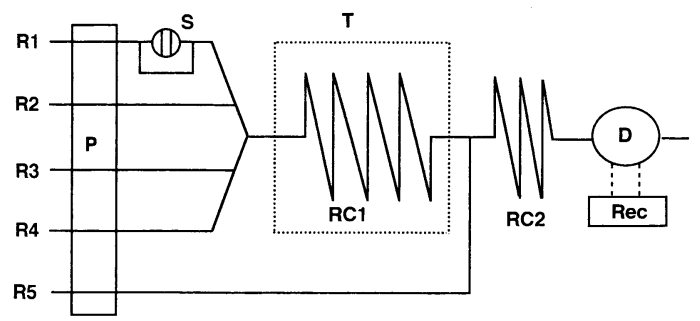

Fig. 6 Flow system for the determination of $\mathrm{Mn}$ (II)

$\mathrm{R} 1$ : carrier $\left(1 \times 10^{-3} \mathrm{M} \mathrm{HCl}\right)$; $\mathrm{R} 2: \mathrm{H}_{2} \mathrm{O}_{2}(0.3 \mathrm{M})$; R3: CAPS $\left(1.0 \times 10^{-2} \mathrm{M}\right)+$ phen $\left(5.0 \times 10^{-2} \mathrm{M}\right)$ : R4: PPDA $\left(1.0 \times 10^{-3} \mathrm{M}\right)+$ Tween $80(0.5 \% \mathrm{w} / \mathrm{v})$; R5: PPDA $\left(1.0 \times 10^{-3} \mathrm{M}\right)+$ Tween $80(0.5 \% \mathrm{w} / \mathrm{v})+$ $\mathrm{H}_{2} \mathrm{SO}_{4}(1.0 \mathrm{M})$; $\mathrm{P}$ : micropump ( $\mathrm{Rl} \sim \mathrm{R} 4: 0.8 \mathrm{ml}$ $\min ^{-1}$; R5: $\left.1.6 \mathrm{ml} \mathrm{min}^{-1}\right) ; \mathrm{S}$ : sample injector valve $(188 \mu \mathrm{l})$; RC1: primary reaction coil $(10 \mathrm{~m})$; RC2 : secondary reaction coil $(8 \mathrm{~m})$; $\mathrm{T}$ : thermostated bath $\left(55^{\circ} \mathrm{C}\right)$; D: detector $(775 \mathrm{~nm})$; Rec: recorder; $\mathrm{W}$ : waste
4 3-メチル-2-ベンゾチアゾリノンヒドラゾンを 基質とした酸化カップリング反応を用いる銅 (II)，コバルト (II)，マンガン (II) 及びクロム （III）の分析

3-メチル-2-ベンゾチアゾリノンヒドラゾン（MBTH） は, 脂肪族アルデヒド類, 芳香族アミン類などの分析試 薬として知られ, 又 DMA などとの酸化カップリング反 応は酵素反応と組み合わせて過酸化水素の定量に用いら れている ${ }^{43) 44)}$.

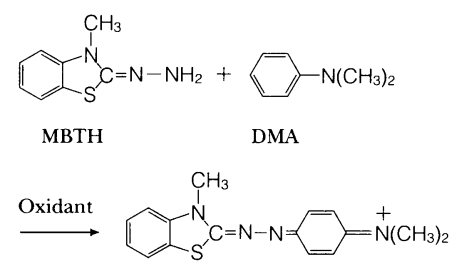

Blue-violet compound $\left(\lambda_{\max }=590 \mathrm{~nm}\right)$

著者らは, 溶存酸素や過酸化水素の存在下で $\mathrm{MBTH}^{-}$ DMAの反応が中性〜アルカリ性の溶液中で微量の $\mathrm{Cu}(\mathrm{II}), \mathrm{Cr}(\mathrm{III})$ 及び $\mathrm{Mn}(\mathrm{II})$ により接触的に促進される ことを見いだしたので，これらの金属イオンの接触分析 を検討した。バッチ法により得られた $\mathrm{Cu}(\mathrm{II}), \mathrm{Cr}(\mathrm{III})$ 及び $\mathrm{Mn}(\mathrm{II})$ の接触作用に対する $\mathrm{pH}$ の影響を Fig. 7 に 示す. 又, $\mathrm{Co}(\mathrm{II})$ も本反応系に接触作用を示したので, FIA 法により検討した.

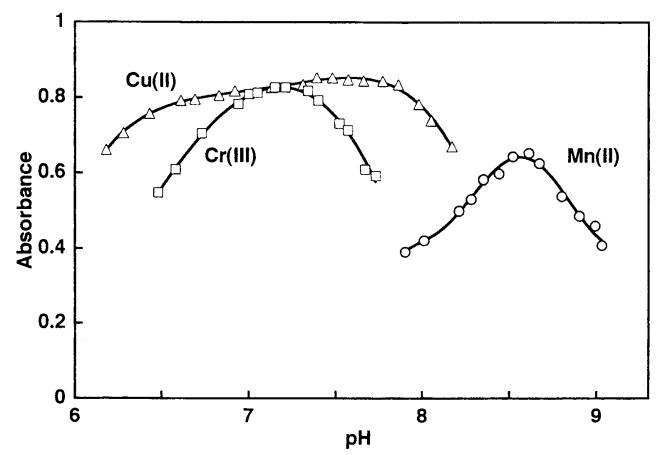

Fig. 7 Effect of $\mathrm{pH}$ on the metal-catalyzed reaction of MBTH with DMA in the presence of hydrogen peroxide or dissolved oxygen

$C_{\mathrm{Cu}(\mathrm{II})}, 1.0 \mathrm{ng} \mathrm{ml}^{-1} ; C_{\mathrm{Cr}(\mathrm{III})}, 6.0 \mathrm{ng} \mathrm{ml}^{-1} ; C_{\mathrm{Mn}(\mathrm{II})}, 1.0 \mathrm{ng}$ $\mathrm{ml}^{-1}$. Other conditions as in the text. 


\section{$4 \cdot 1 \mathrm{Cu}(\mathrm{II})$ の分析法}

4・1・1 バッチ法 MBTH-DMA- $\mathrm{H}_{2} \mathrm{O}_{2}$ の反応系に おける $\mathrm{Cu}(\mathrm{II})$ の接触作用は中性付近で顕著に起こり (Fig. 7), 又アンモニアの活性化効果が認められた。ア ンモニア共存下で 4 種の緩衝剤の影響を検討したとこ ろ，接触反応に影響しない 2,4,6-トリメチルピリジン （TMP）を緩衝剤として選んだ。分析条件は次のとおり である ${ }^{32)} . C_{\mathrm{MBTH}}=4.0 \times 10^{-5} \mathrm{M}, C_{\mathrm{DMA}}=2.8 \times 10^{-3} \mathrm{M}$, $C_{\mathrm{H}_{2} \mathrm{O}_{2}}=5.0 \times 10^{-2} \mathrm{M}, C_{\mathrm{NH}_{3}}=5.4 \times 10^{-2} \mathrm{M}, C_{\mathrm{TMP}}=$ $1.2 \times 10^{-2} \mathrm{M}$, 反応 $\mathrm{pH}=5.0 \sim 5.2$, 反応温度 $=45^{\circ} \mathrm{C}$, 反応時間 $=20$ 分. この条件下で得られた検量線は, 1.2 $\mathrm{ng} \mathrm{ml} \mathrm{m}^{-1}$ までの範囲で良好な直線性を示した。これより 求めた Sandell 感度は $1.3 \times 10^{-3} \mathrm{ng} \mathrm{cm}^{-2}$ となり, RSD は $2.6 \%\left(n=5, C_{\mathrm{Cu}(\mathrm{II})}=1.0 \mathrm{ng} \mathrm{ml}^{-1}\right)$ であった．共存 イオンの影響を検討したところ, 約 3 倍量以上の $\mathrm{Co}(\mathrm{II}), 16$ 倍量以上の Sn(II, IV) は妨害した. しかし, 他のイオンは 30 倍量でも妨害しなかった. 本法を水道 水, 河川水及び海水試料に応用し, 併せて DPD-DMA 反応系 ${ }^{30)}$, PPDA-DMA 反応系 ${ }^{33)}$ を用いる接触分析法 （いずれもバッチ法）及びフレームレス原子吸光法 （FAAS）と比較した（Table 3). 水道水及び河川水試料 については DPD-DMA 法, PPDA-DMA 法により得ら れた值と一致した. 河川水の場合, 本法による分析値は FAAS 法により得られた值より低く，天然水中に含まれ る有機物の影響が考えられたので, 試料を酸分解した
後, 本法を適用した.この值は FAAS 法による值と一致 したことから, 酸分解しない試料の分析值は, 天然水中 の反応活性な $\mathrm{Cu}$ の化学種濃度であることが知られた。 DMA の代わりに $N$-エチル- $N$ - (2-ヒドロキシ-3-スルホプ ロピル)- $m$-アニシジン, $N$-エチル- $N$-(2-ヒドロキシ-3-ス ルホプロピル)-3,5-ジメトキシアニリン（DAOS）など 6 種の新トリンダー試薬を用いて, $\mathrm{Cu}(\mathrm{II})$ の接触作用を 検討した ${ }^{35)}$. その中で DAOSを用いた場合, $\mathrm{Cu}(\mathrm{II})$ の 接触作用が著しく大きく, DMAの場合に比べて試薬空 試験液との吸光度差（反応時間 5 分）は 30 倍となった. 又, $\mathrm{MBTH}-\mathrm{DAOS}-\mathrm{H}_{2} \mathrm{O}_{2}-\mathrm{Cu}(\mathrm{II})$ 系において bpy, phen, py 及び 2.2' : 6',2"-ターピリジン（terpy）の活性 化効果を調べたところ, py が最も効果的な活性化剂で あった. $\mathrm{Cu}(\mathrm{II})$ の接触作用は $\mathrm{pH} 6$ 付近で最も著しかっ たので, 緩衝剤として 3-(N-モルホリノ)-2-ヒドロキシ ルプロパン酸（MOPSO）を用いて定量条件を検討した. その結果, 各試薬濃度は, $C_{\mathrm{MBTH}}=3.0 \times 10^{-4} \mathrm{M}$, $C_{\mathrm{DAOS}}=3.0 \times 10^{-4} \mathrm{M}, C_{\mathrm{H}_{2} \mathrm{O}_{2}}=0.3 \mathrm{M}, C_{\mathrm{py}}=1.0 \times 10^{-2} \mathrm{M}$, $C_{\text {MOPSO }}=3.0 \times 10^{-3} \mathrm{M}$ となり, $\mathrm{pH} 5.6$, 反応温度 $30^{\circ} \mathrm{C}$ で反応開始 7.5 あるいは 15 分後に $525 \mathrm{~nm}$ の吸光度を 測定することにした。この方法において反応時間を 7.5 分とすると, $0.02 \sim 0.1 \mathrm{ng} \mathrm{ml}^{-1}$ の, 又 15 分の場合, $0.002 \sim 0.008 \mathrm{ng} \mathrm{ml}^{-1}$ の濃度範囲で $\mathrm{Cu}($ II) が定量可能 となり, 最も高感度な分析法の一つとなった。 RSD は $2.6 \%\left(n=10, C_{\mathrm{Cu}(\mathrm{II})}=0.06 \mathrm{ng} \mathrm{ml}^{-1}\right)$ となり再現性も

Table 3 Determination of copper in tap, river and seawater samples

\begin{tabular}{|c|c|c|c|c|c|}
\hline Sample & Method & $\begin{array}{l}\text { Sample } \\
\text { taken } / \mathrm{ml}\end{array}$ & $\begin{array}{l}\mathrm{Cu}(\mathrm{II}) \\
\text { added/ng }\end{array}$ & $\begin{array}{c}\text { Cu found } \text { fe }^{\mathrm{e}} / \\
\text { ng }\end{array}$ & $\begin{array}{c}\mathrm{Cu} \text { in sample } \mathrm{e}^{\mathrm{e}} / \\
\mathrm{ng} \mathrm{m}^{-1}\end{array}$ \\
\hline \multirow[t]{6}{*}{ Tap water ${ }^{\text {a) }}$} & MBTH-DMA $^{32)}$ & 20 & 0 & $21.2 \pm 0.2$ & $1.08 \pm 0.01$ \\
\hline & & 20 & 10 & $32.5 \pm 0.4$ & $1.14 \pm 0.02$ \\
\hline & DPD-DMA $^{30)}$ & 20 & 0 & $21.2 \pm 0.2$ & $1.08 \pm 0.01$ \\
\hline & & 20 & 10 & $39.3 \pm 0.4$ & $0.98 \pm 0.02$ \\
\hline & PPDA-DMA $^{15)}$ & 20 & 0 & $21.0 \pm 1.3$ & $1.07 \pm 0.07$ \\
\hline & & 20 & 10 & $42.2 \pm 2.5$ & $1.13 \pm 0.13$ \\
\hline \multirow[t]{6}{*}{ River water ${ }^{\text {b) }}$} & MBTH-DMA ${ }^{32)}$ & 20 & 0 & $21.1 \pm 1.0$ & $1.08 \pm 0.05$ \\
\hline & & 20 & 10 & $26.5 \pm 0.5$ & $0.79 \pm 0.03$ \\
\hline & DPD-DMA $^{30)}$ & 20 & 0 & $20.5 \pm 1.3$ & $1.04 \pm 0.07$ \\
\hline & & 20 & 10 & $38.7 \pm 1.0$ & $0.95 \pm 0.05$ \\
\hline & PPDA-DMA $^{15)}$ & 20 & 0 & $20.2 \pm 1.3$ & $1.02 \pm 0.07$ \\
\hline & & 20 & 10 & $41.0 \pm 2.3$ & $1.06 \pm 0.12$ \\
\hline \multicolumn{6}{|l|}{ Seawater } \\
\hline \multirow[t]{2}{*}{$(1)^{c)}$} & MBTH-DMA ${ }^{32)}$ & 25 & 0 & $7.2 \pm 0.7$ & $0.30 \pm 0.03$ \\
\hline & & 25 & 10 & $18.0 \pm 0.4$ & $0.32 \pm 0.01$ \\
\hline \multirow[t]{2}{*}{$(2)^{d)}$} & MBTH-DMA ${ }^{32)}$ & 20 & 0 & $8.4 \pm 0.4$ & $0.43 \pm 0.02$ \\
\hline & & 20 & 10 & $30.1 \pm 0.5$ & $0.51 \pm 0.03$ \\
\hline
\end{tabular}

The values obtained by FAAS are a) 1.3 , b) 1.9 , c) 0.4 and d) $0.5 \mathrm{ng} \mathrm{ml}^{-1}$, e) Corrected for addition $(n=3)$. 
良好であった. $\mathrm{Cr}(\mathrm{VI}), \mathrm{Mn}(\mathrm{II})$ 及び $\mathrm{Se}(\mathrm{IV})$ を除く共存 イオンは $10^{3}$ 倍量の共存でも影響しなかった. Mn(II) 及び $\mathrm{Se}(\mathrm{IV})$ は $10^{2}$ 倍量まで, $\mathrm{Cr}(\mathrm{VI})$ は 10 倍量まで許容 できた. $\mathrm{Cr}(\mathrm{III})$ が $10^{3}$ 倍量で妨害しなかったので, $\mathrm{Cr}(\mathrm{VI})$ はあらかじめ $\mathrm{Cr}(\mathrm{III})$ に還元しておくことにより その妨害を除くことができた。本法は環境標準試料（国 立公害研究所製）の人髮（NIES, No. 5) 中の Mn の定 量に応用し, 得られた值は保証值と良く一致した。

$4 \cdot 1 \cdot 2$ FIA 法 ${ }^{36)} \quad \mathrm{MBTH}-\mathrm{DMA}-\mathrm{H}_{2} \mathrm{O}_{2}-\mathrm{Cu}(\mathrm{II})$ 系を FIA 法にも適用した。この場合, bpy, phen, py, 2,9ジメチル-1,10-フェナントロリン（Me - -phen）及び terpy の活性化効果の程度を調べた. その結果, terpy 以外の 配位子には活性化作用が認められ, その効果の大きさは, bpy $\sim$ phen $\gg \mathrm{Me}_{2}$-phen $>$ py となった. 本分析法では, 濃度依存性のより少ない bpyを活性化剂として用いた。 フローシステムは Fig. 1 と同様な 4 流路のものを組み 立てた. R1よりキャリヤー溶液 $(0.1 \mathrm{M} \mathrm{HCl}), \mathrm{R} 2$ より MBTH $\left(3.0 \times 10^{-4} \mathrm{M}\right)$ と DMA $\left(8.0 \times 10^{-3} \mathrm{M}\right)$ の混合 溶液, R3 より過酸化水素 $(0.5 \mathrm{M})$ と bpy $\left(4.0 \times 10^{-3}\right.$ M）の混合溶液, R4 上り緩衝剤としての 3- $(N-$-モルホリ ノ)プロパンスルホン酸溶液（0.1 M）を送液した（0.5 $\left.\mathrm{ml} \mathrm{min}{ }^{-1}\right)$. 反応温度を $50^{\circ} \mathrm{C}$, 反応 $\mathrm{pH}$ を $7.2 \sim 7.4$, 反 応コイルを $5 \mathrm{~m}$ として反応生成物の吸光度 $(590 \mathrm{~nm})$ を測定した。試料量 $141 \mu \mathrm{l}$ での検出限界 $(S / N=3)$ は $0.05 \mathrm{ng} \mathrm{ml}^{-1}$ で, $\mathrm{RSD}$ は $2.1 \% \quad\left(n=10, \quad C_{\mathrm{Cu}(\mathrm{II})}=4 \mathrm{ng}\right.$ $\mathrm{ml}^{-1}$ ) であった.

\section{$4 \cdot 2$ マンガン(II) の分析法}

4·2・1 バッチ法 ${ }^{37}$ MBTH-DMAの反応において 溶存酸素を酸化剂とすると, $\mathrm{Mn}(\mathrm{II})$ は $\mathrm{pH} 8.6$ 付近で顕 著な接触作用を示したので（Fig. 7), 緩衝剤としてト リス(ヒドロキシル)アミノメタン（Tris）を用いた，又， 活性化剤として phen 及び bpy の作用について検討した ところ，いずれも感度の上昇を認めた。ここでは，100 倍量の $\mathrm{Fe}(\mathrm{III})$ 及び $\mathrm{Co}(\mathrm{II})$ を許容できる phen を活性化 剤として選んだ. 各試薬濃度は, $C_{\mathrm{MBTH}}=8.0 \times 10^{-4} \mathrm{M}$, $C_{\mathrm{DMA}}=6.4 \times 10^{-3} \mathrm{M}, C_{\text {phen }}=4.0 \times 10^{-4} \mathrm{M}, C_{\text {Tris }}=$ $2.0 \times 10^{-2} \mathrm{M}$ とし, $\mathrm{pH} 8.6$, 反応温度 $30^{\circ} \mathrm{C}$ で反応開始 50 分後に $590 \mathrm{~nm}$ の吸光度を測定した. 本法により0〜 $2.0 \mathrm{ng} \mathrm{ml}^{-1}$ の Mn(II) が定量可能となった. 検量線はわ ずかに湾曲となったが, RSD は $2.9 \% \quad\left(n=9, C_{\mathrm{Mn}(\mathrm{II})}=\right.$ $1.0 \mathrm{ng} \mathrm{ml}^{-1}$ ) となり満足できる再現性となった。共存イ オンの影響を検討したところ, 約 20 倍量以上の $\mathrm{Cu}(\mathrm{II})$ は妨害したが, 他のイオンは 200 倍量でも妨害しなか った. 本法を水道水, 河川水, 湖沼水及び海水中の $\mathrm{Mn}$
の定量に応用し，FAAS 法による值と一致した。

4・2・2 FIA 法 ${ }^{39)}$ MBTH-DMA の反応系で酸化剂 を過酸化水素として Mn(II) の分析を FIA 法により検討 した.この場合も $\mathrm{pH} 8.5$ 付近で最大の接触作用が認め

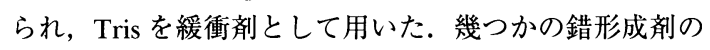
活性化効果を調べ, その中でクエン酸塩と phen を同時 に使用することにより感度の上昇が認められた．Fig. 1 と同様な 4 流路のフロー系において R1 より $1.2 \%$ 過酸 化水素水, $\mathrm{R} 2$ より $0.1 \mathrm{M}$ クエン酸塩及び $0.2 \mathrm{M}$ Trisの 混合溶液, R3 より $3.0 \times 10^{-2} \mathrm{M}$ DMA 溶液, R4より $3.0 \times 10^{-3} \mathrm{M}$ MBTH 及び $3.0 \times 10^{-3} \mathrm{M}$ phen の混合溶液 が送液される $\left(1.35 \mathrm{ml} \mathrm{min}^{-1}\right)$. 試料溶液 $(620 \mu \mathrm{l})$ は, 過酸化水素水の流れに注入され, 恒温槽 $\left(50^{\circ} \mathrm{C}\right)$ に浸 した反応コイル内（5 m) で色素の生成が進行する. $25^{\circ} \mathrm{C}$ の冷却コイルを通過した生成物の吸光度 $(590 \mathrm{~nm})$ が測定される。この方法により 2〜30 $\mathrm{ng} \mathrm{m}^{-1}$ の $\mathrm{Mn}$ (II) が定量可能で, RSD は $4.3 \% \quad\left(n=10, C_{\mathrm{Mn}(\mathrm{II})}=\right.$ $10 \mathrm{ng} \mathrm{ml}^{-1}$ ) となり, 分析速度は 10 試料/時であった。 約 2 倍量以上の $\mathrm{Cu}(\mathrm{II})$ の共存は妨害を示したが, 100 倍量の他のイオンは許容できた. 本法によりリョウブ (NIES No. 1)，クロレラ（NIES No.3）及び茶葉 (NIES No. 7) 中の Mn を定量し, 得られた值は保証值 と良く一致した。

\section{$4 \cdot 3$ クロム(III) の分析法 ${ }^{28)}$}

MBTH-DMA- $\mathrm{H}_{2} \mathrm{O}_{2}$ 反応における $\mathrm{Cr}(\mathrm{III})$ の接触作用 は中性付近で顕著であったので（Fig. 7), 緩衝剂とし て TMPを用いた. 又, Fig. 8 に示したようにEDTA 濃 度の増加とともに吸光度は上昇し（反応時間 50 分）,

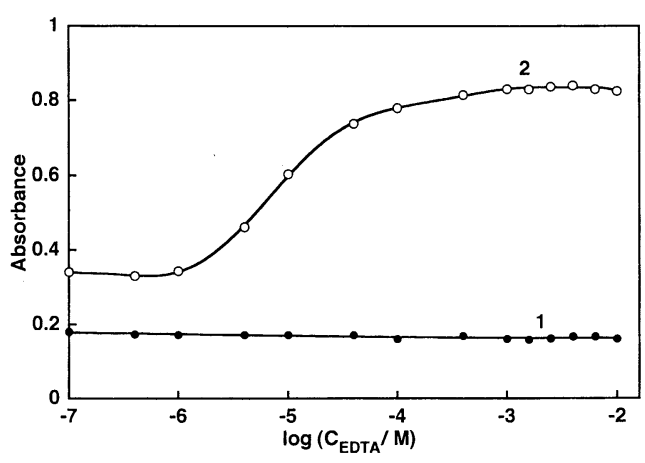

Fig. 8 Effect of EDTA on the uncatalyzed (1) and catalyzed (2) reactions of MBTH with DMA in the presence of hydrogen peroxide

$C_{\mathrm{Cr} \text { (III) }}, 6.0 \mathrm{ng} \mathrm{ml}^{-1}$. Other conditions as in the text. 
最適濃度での吸光度は, EDTA を添加しない場合に比べ て約 2.5 倍となった．各試薬濃度は, $C_{\mathrm{MBTH}}=6.0 \times 10^{-5}$ $\mathrm{M}, C_{\mathrm{DMA}}=5.6 \times 10^{-3} \mathrm{M}, C_{\mathrm{H}_{2} \mathrm{O}_{2}}=0.24 \mathrm{M}, C_{\mathrm{EDTA}}=3.2 \times$ $10^{-3} \mathrm{M}, C_{\mathrm{TMP}}=1.5 \times 10^{-2} \mathrm{M}$ とし, $\mathrm{pH} 7.1 \sim 7.3$, 反応 温度 $45^{\circ} \mathrm{C}$ で反応開始 50 分後に $590 \mathrm{~nm}$ の吸光度を測定 した.この操作により $0.4 \sim 10 \mathrm{ng} \mathrm{ml}^{-1}$ の範囲で作成し た $\mathrm{Cr}(\mathrm{III})$ の検量線はわずかに湾曲したが，RSDは $3.5 \%\left(n=8, C_{\mathrm{Cr}(\mathrm{III})}=4 \mathrm{ng} \mathrm{ml}^{-1}\right)$ と再現性は良好であ った. $\mathrm{Cr}(\mathrm{VI})$ はこの反応に触媒として作用しなかった ので，エ夕ノールにより $\mathrm{Cr}$ (III) に還元した後，定量可 能となった。ほとんどの共存イオンは，5倍量で妨害し なかったが， 5 倍量の Fe(II, III) は正の妨害を与えるた め,これを分離する必要があった。

\section{$4 \cdot 4$ コバルト(II) の分析法 ${ }^{21)}$}

$\mathrm{MBTH}-\mathrm{DMA}-\mathrm{H}_{2} \mathrm{O}_{2}$ の反応において $\mathrm{pH} 8$ 付近で Co(II) の著しい接触作用が認められた。そこで, 緩衝 剂として Tris を用いた. 本反応系では, Tiron と炭酸水 素イオンが同時に活性化剂として作用し，感度を高め た，又，陽イオン性，陰イオン性及び非イオン性の界面 活性剤の効果を調べ，そのうち SDS が最も感度を上昇 させた.フロー系は Fig. 1 と同様な 4 流路のシステム を用いた. R1 よりキャリヤー溶液 $\left(1.0 \times 10^{-2} \mathrm{M}\right.$ 塩酸 $)$, $\mathrm{R} 2$ より過酸化水素 $(0.3 \mathrm{M})$ と Tiron $\left(6.0 \times 10^{-2} \mathrm{M}\right)$ の混合溶液, R3 より DMA 溶液 $\left(3.0 \times 10^{-2} \mathrm{M}\right), \mathrm{R} 4$ よ り $\mathrm{MBTH}\left(2.5 \times 10^{-3} \mathrm{M}\right)$, SDS $\left(2.0 \times 10^{-2} \mathrm{M}\right)$ 及び Tris $\left(8.0 \times 10^{-2} \mathrm{M}\right)$ の混合溶液が送液される（1.0 ml $\left.\min ^{-1}\right)$. 試料溶液 $(160 \mu \mathrm{l})$ はキャリヤー溶液の流れに
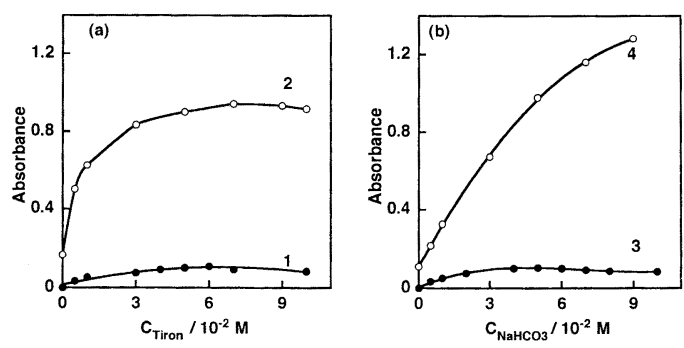

Fig. 9 Effects of Tiron (a) and hydrogencarbonate (b) concentrations on the Co(II)-catalyzed reaction of MBTH with DMA in the presence of hydrogen peroxide

1: Tiron; 2: Tiron with hydrogencarbonate $(5.0 \times$ $\left.10^{-2} \mathrm{M}\right) ; 3$ : hydrogencarbonate; 4 : hydrogencarbonate with Tiron $\left(6.0 \times 10^{-2} \mathrm{M}\right) . \quad C_{\mathrm{Co}(\mathrm{II})}, 2.0 \mathrm{ng}$ $\mathrm{ml}^{-1}$.
注入される，反応コイル $\left(5 \mathrm{~m}, 70^{\circ} \mathrm{C}\right)$ で色素の生成が 速められるので, 生成物の吸光度 $(590 \mathrm{~nm})$ が追跡さ れる.

Fig. 9 に Tiron 及び炭酸水素イオン濃度の影響を示 す。これより明らかなように一つの配位子の存在だけで は接触反応速度はそれほど速められることはないが，両 者の存在によりこの速度は著しく増大することが分か る. 本法では, 検出器の感度を変えることにより 0.04 〜 $0.2 \mathrm{ng} \mathrm{ml}^{-1}$ 及び $0.1 \sim 0.5 \mathrm{ng} \mathrm{ml}^{-1}$ の二つの濃度領域 で $\mathrm{Co}(\mathrm{II})$ の定量ができ， RSD は $2.3 \% \quad(n=10$, $C_{\text {Co(II) }}=0.04 \mathrm{ng} \mathrm{ml}^{-1}$ ) であった. 50 倍量のほとんどの 共存イオンは影響を与えなかったが, Cu(II) が著しい 妨害を示した。 そこで，そのマスキング剂として Trien を用い, リョウブ（NIES No. 1) 中のコバルトを分析し たところ，保証值と良く一致した值が得られた。

5 4-アミノアンチピリンと $N, N$-ジメチルアニリ ンの酸化カップリング反応を用いるバナジウ 厶 $(\mathrm{IV}, \mathrm{V})$ の分析

4-アミノアンチピリン（AA）は，酸化剂の存在下， フェノール, DMA などとカップリングして色素を生成 するので, これらのカップラーの検出あるいは䤃素反応 と組み合わせて生体成分の分析に用いられている ${ }^{43) 44)}$.

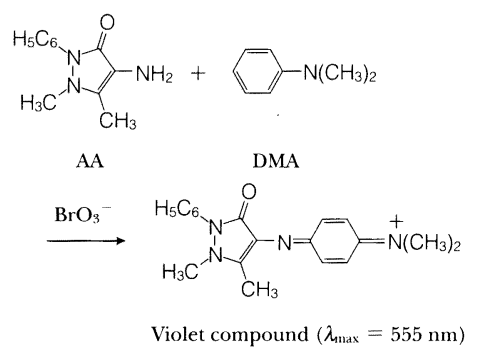

AA と DMA の反応に酸化剂として臭素酸塩を用いる と, $\mathrm{V}(\mathrm{IV}, \mathrm{V})$ がこの酸化カップリング反応を接触的に促 進する. そこで，この反応系を用いて V IV , V ) の接触 分析を確立した.

\section{$5 \cdot 1 \quad ハ ゙ ッ チ^{2}{ }^{26)}$}

$\mathrm{AA}-\mathrm{DMA}-\mathrm{BrO}_{3}{ }^{-}$系での $\mathrm{V}(\mathrm{V})$ の接触作用は $\mathrm{pH} 3.5$ 以 下で顕著に起こり, 活性化剂として5-スルホサリチル 酸（SSA）を添加するとその接触作用は著しく増大した (Fig. 10). 又，この反応系でV(IV) も同様な接触作用 を示したので，バッチ法により $\mathrm{V}(\mathrm{IV}, \mathrm{V})$ の分析の基礎 的条件を検討した。それぞれの試薬濃度を， $C_{\mathrm{AA}}=$ 
$6.8 \times 10^{-4} \mathrm{M}, \quad C_{\mathrm{DMA}}=8.0 \times 10^{-3} \mathrm{M}, \quad C_{\mathrm{BrO}_{4}}=6.0 \times 10^{-3}$ $\mathrm{M}, C_{\mathrm{SSA}}=8.0 \times 10^{-2} \mathrm{M}$ とし, $\mathrm{pH} 2.9$, 反応温度 $50^{\circ} \mathrm{C}$ で反応開始 20 分後に $555 \mathrm{~nm}$ の吸光度を測定した。 $\mathrm{V}(\mathrm{V})$ の検量線は, $0.1 \sim 1.0 \mathrm{ng} \mathrm{ml}^{-1}$ の範囲で Beerの法 則に従い,これより求めた Sandell 感度は, $1.1 \times 10^{-3}$ $\mathrm{ng} \mathrm{cm}{ }^{-2}$ で, RSD は $1.8 \%\left(n=10, C_{N(\mathrm{~V})}=0.2 \mathrm{ng} \mathrm{ml}^{-1}\right)$ であった，又， V(IV) の検量線も V(V) のそれと誤差の 範囲内で一致した，共存イオンの影響を調べたところ， 約 170 倍量の $\mathrm{Cu}(\mathrm{II})$ 及び $\mathrm{Fe}(\mathrm{II}, \mathrm{III})$ は妨害したが，30 倍量では妨害を示さなくなった. 本法を, 水道水, 河川

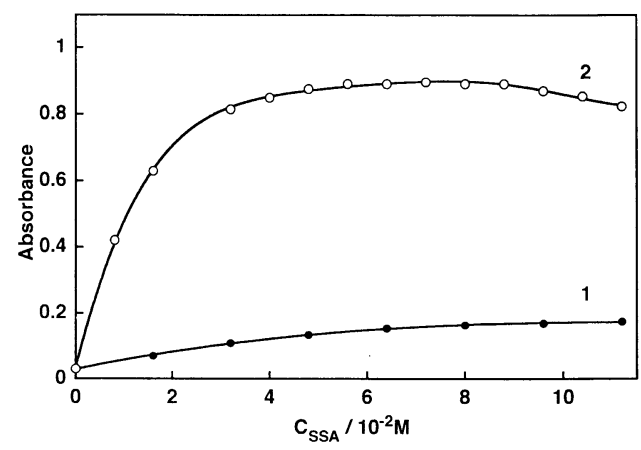

Fig. 10 Effect of 5-sulfosalicylic acid concentration on the uncatalyzed (1) and catalyzed (2) reactions of AA with DMA in the presence of bromate $C_{V(\mathrm{~V})}, 0.8 \mathrm{ng} \mathrm{ml}^{-1}$. Other conditions as in the text.
水, 湖沼水及び海水中の Vの定量に応用した.

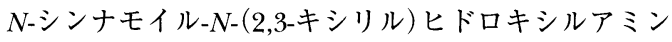
（CXA）は強酸酸性において V(V) と錯形成し，この錯 体が有機溶媒に抽出されることが報告されていたの で5), 著者らは, CXA-V 錯体のトルエン抽出について 検討した ${ }^{27)}$.これにより V(IV)- 及びV(V)-CXA 錯体が 異なる $\mathrm{pH}$ で抽出されること, すなわち, V(V)-CXA 錯 体は $\mathrm{pH} 2$ で, V(IV) - CXA 錯体は $\mathrm{pH} 5.5$ でトルエン相 に抽出されることを見いだした. 又, 両方の錯体ともア ルカリ水溶液に逆抽出されたので, この逆抽出液中の $\mathrm{V}(\mathrm{IV})$ と $\mathrm{V}(\mathrm{V})$ を上述の分析法で分析することにより $\mathrm{V}(\mathrm{IV})$ と $\mathrm{V}(\mathrm{V})$ の分別定量法を開発した. 本法を水道水, 河川水, 湖沼水及び海水の $\mathrm{V}(\mathrm{IV})$ と $\mathrm{V}(\mathrm{V})$ の分別定量に 応用した (Table 4). これらの結果は検討の余地があ るものの Vは水道水中には $\mathrm{V}(\mathrm{V})$ として, 又河川水, 湖 沼水及び海水中には主として $\mathrm{V}(\mathrm{IV})$ として存在してい ることが明らかとなった。

\section{$5 \cdot 2$ FIA 法 $^{20)}$}

$\mathrm{AA}-\mathrm{DMA}-\mathrm{BrO}_{3}{ }^{-}-\mathrm{V}(\mathrm{IV}, \mathrm{V})$ の反応系を FIA 法に適用 した。バッチ法に比べ FIA 法では反応時間が短く, バ ッチ法で得られた条件をそのまま適用したのでは高感度 は望めない.そこで感度の上昇を図るため SSA を含む 幾つかの錯形成剤についてその活性化作用を検討し，そ の中でTironを活性化剂として選んだ．又， pH 2.6〜 2.7 で V(V) の接触作用が著しかったので, 緩衝剂とし

Table 4 Fractional determination of $\mathrm{V}(\mathrm{V})$ and $\mathrm{V}(\mathrm{IV})$ in river, lake and seawater samples

\begin{tabular}{|c|c|c|c|c|c|c|c|c|}
\hline \multirow{2}{*}{ Sample } & \multirow{2}{*}{$\begin{array}{c}\text { Sample } \\
\text { taken/ } \\
\text { ml }\end{array}$} & \multicolumn{2}{|c|}{$\mathrm{V}$ added/ng } & \multicolumn{2}{|c|}{$\mathrm{V}$ found $^{\text {a) }} / \mathrm{ng}$} & \multicolumn{2}{|c|}{$\mathrm{V}$ in sample $\mathrm{ang} \mathrm{ml}^{-1}$} & \multirow{2}{*}{ Total } \\
\hline & & $\mathrm{V}(\mathrm{IV})$ & $\mathrm{V}(\mathrm{V})$ & $\mathrm{V}(\mathrm{IV})$ & $\mathrm{V}(\mathrm{V})$ & $\mathrm{V}(\mathrm{IV})$ & $\mathrm{V}(\mathrm{V})$ & \\
\hline \multicolumn{9}{|l|}{ River water } \\
\hline \multirow[t]{2}{*}{ Tenjin-gawa } & 20 & 0 & 0 & 8.7 & 0.7 & $0.4_{0}$ & $0.0_{4}$ & \multirow[t]{2}{*}{$0.4_{6}$} \\
\hline & 20 & 10 & 10 & 18.9 & 9.4 & $0.4_{5}$ & 0.0 & \\
\hline \multirow[t]{2}{*}{ Sendai-gawa } & 20 & 0 & 0 & 5.4 & 0.9 & $0.2_{7}$ & $0.0_{5}$ & \multirow[t]{2}{*}{$0.3_{6}$} \\
\hline & 20 & 10 & 10 & 16.4 & 10.5 & $0.3_{2}$ & $0.0_{3}$ & \\
\hline \multicolumn{9}{|l|}{ Lake water } \\
\hline \multirow[t]{2}{*}{ Togo-ike } & 20 & 0 & 0 & 8.4 & 1.5 & $0.4_{3}$ & $0.0_{8}$ & \multirow[t]{2}{*}{$0.5_{2}$} \\
\hline & 20 & 10 & 10 & 18.5 & 11.9 & $0.4_{3}$ & $0.1_{0}$ & \\
\hline \multirow[t]{2}{*}{ Koyama-ike } & 20 & 0 & 0 & 2.3 & 0.9 & $0.1_{2}$ & $0.0_{5}$ & \multirow[t]{2}{*}{$0.1_{4}$} \\
\hline & 20 & 10 & 10 & 12.4 & 11.0 & $0.1_{2}$ & $0.0_{5}$ & \\
\hline \multicolumn{9}{|l|}{ Seawater } \\
\hline \multirow[t]{2}{*}{ Hawai } & 5 & 0 & 0 & 6.4 & 1.0 & $1.2_{8}$ & $0.2_{0}$ & \multirow[t]{2}{*}{$1.8_{0}$} \\
\hline & 5 & 10 & 10 & 16.7 & 11.1 & $1.3_{4}$ & $0.2_{2}$ & \\
\hline \multirow[t]{2}{*}{ Karao } & 5 & 0 & 0 & 6.7 & 0.4 & $1.3_{4}$ & $0.0_{8}$ & \multirow[t]{2}{*}{$1.8_{5}$} \\
\hline & 5 & 10 & 10 & 16.4 & 10.4 & $1.3_{0}$ & $0.0_{8}$ & \\
\hline
\end{tabular}

a) Corrected for addtion $(n=3)$. 
てギ酸塩を用いた.

Fig. 1 と同様な 4 流路のフロー系において, R1 より キャリヤー溶液 (0.1 M 塩酸), R2より AA $\left(4.0 \times 10^{-3}\right.$ M), DMA $\left(3.0 \times 10^{-2} \mathrm{M}\right)$ 及び Tiron $(0.1 \mathrm{M})$ の混合 溶液, $\mathrm{R} 3$ より臭素酸塩溶液 $\left(8.0 \times 10^{-2} \mathrm{M}\right), \mathrm{R} 4$ よりギ 酸塩（0.15 M) がそれぞれ送液される $\left(0.8 \mathrm{ml} \mathrm{min}^{-1}\right)$. キャリヤー溶液中に注入された試料溶液 $(200 \mu \mathrm{l})$ の V により反応コイル内 $\left(10 \mathrm{~m}, 55^{\circ} \mathrm{C}\right)$ での色素生成が進 むので, この吸光度 $(555 \mathrm{~nm})$ が測定される.

以上の条件でピーク高さと V $(\mathrm{IV})$ 及び $\mathrm{V}(\mathrm{V})$ 濃度に は, $0.05 \sim 2.0 \mathrm{ng} \mathrm{ml}^{-1}$ の範囲で良好な直線関係が得ら れ, $\operatorname{RSD}$ は $0.8 \%\left(n=10, C_{\mathrm{V}(\mathrm{V})}=1.0 \mathrm{ng} \mathrm{m}^{-1}\right)$ であっ た. $10^{2}$ 倍量の金属イオン及び $10^{4}$ 倍量の陰イオンの共 存で妨害はなく，選択性は良好であった．本法を河川水

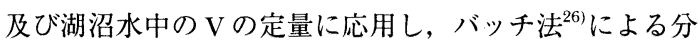
析値と一致した。

$$
6 \text { 結 言 }
$$

吸光光度法を用いた接触分析において測定される物質 は大きなモル吸光係数を有していることが望ましく, 又 退色反応より発色反応を用いたほうが好都合である. 酸 化カップリング反応はこのような条件を備えている.こ れらの反応系を用いた金属イオンの接触分析の幾つかを 開発し，実試料の分析に応用した．本論文では，同一の 酸化還元反応系で複数の金属イオンが触媒として作用す るものの錯形成剤を，活性化剂あるいはマスキング剤と して適切に使いわけ, $\mathrm{pH}$ や温度などの反応条件を最適 化することにより, 高感度で選択性の良い分析法が得ら れることを示した．更にはFIA 法の適用により接触分 析の迅速化, 高精度化が達成された. 今後, FIA 法に適 した新しい反応系の開発及び配位子による活性化作用の 解明が期待される.

本研究は, 筑波大学化学系 河鴧拓治教授及び多くの共同 研究者との長年にわたる共同研究の成果であり, 同教授及 び研究に携わった方々に心より感謝致します。

\section{文献}

1) K. B. Yatsimirskii: "Kinetic Methods of Analysis", (1966), (Pergamon Press, Oxford).

2) P. R. Bontchev: Talanta, 17, 499 (1970); 19, 675 (1972).

3) 河寫拓治, 米原範伸: 分析化学 (Bunseki Kagaku), 21, 825 (1972).

4) 田中元治: ぶんせき (Bunseki), 1976, 426.

5) 中野惠文, 河嶌拓治:ぶんせき (Bunseki), 1987, 317.

6) H. A. Mottola: "Kinetic Aspects of Analytical
Chemistry", (1988), (John Wiley \& Sons, New York).

7) D. Perez-Bendito, M. Silva: "Kinetic Methods in Analytical Chemistry”, (1988), (Ellis Horwood, Chichester).

8) T. Kawashima, S. Nakano: Anal. Chim. Acta, 261, 167 (1992).

9) 手嶋紀雄, 中野惠文, 河嶌拓治: J. Flow Injection Anal., 11, 7 (1994).

10) T. Kawashima, S. Nakano, M. Tabata, M. Tanaka: Trends Anal. Chem., 16, 132 (1997).

11) M. Valcarcel, F. Grases: Talanta, 30, 139 (1983).

12) K. Robards, P. J. Worsfold: Anal. Chim. Acta, 266, 147 (1992).

13) E. B. Sandell, I. M. Kolthoff: J. Am. Chem. Soc., 56, 1426 (1934).

14) S. Nakano, H. Enoki, T. Kawashima: Chem. Lett., 1980, 1173.

15) S. Nakano, M. Odzu, M. Tanaka, T. Kawashima: Mikrochim. Acta, 1983 I, 403.

16) S. Nakano, K. Tsujii, T. Kawashima: Talanta, 42 , 1051 (1995).

17) S. Nakano, M. Sakai, M. Kurachi, T. Kawashima: Microchem. J., 49, 298 (1994).

18) 河嶌拓治, 南 隆郎, 阿多誠文, 鎌田政明, 中 野惠文: J. Flow Injection Anal., 2, 40 (1985).

19) 門脇亮一, 戸田英男, 中野惠文, 河嶌拓治: 日 本分析化学会第 45 年会講演要旨集, p. 305 (1996).

20) S. Nakano, M. Tago, T. Kawashima: Anal. Sci., 5, 69 (1989).

21) Z. Yu, N. Teshima, S. Nakano, T. Kawashima: Talanta, 43, 1519 (1996).

22) S. Nakano, M. Nozawa, M. Yanagawa, T. Kawashima: Anal. Chim. Acta, 261, 183 (1992).

23) 門脇亮一, 中野惠文, 河嶌拓治: 第 58 回分析化 学討論会講演要旨集, p. 94 (1997).

24) 河嶌拓治, 烏丸省子, 橋元美幸, 中野惠文: 日 本化学会誌, 1981, 175.

25) S. Nakano, E. Kasahara, M. Tanaka, T. Kawashima: Chem. Lett., 1981, 597.

26) S. Nakano, C. Yamada, M. Sakai, T. Kawashima: Anal. Sci., 2, 61 (1986).

27) S. Nakano, S. Kinoshita, M. Ikata, T. Kawashima: Anal. Sci., 6, 435 (1990).

28) S. Nakano, S. Hinokuma, T. Kawashima: Chem. Lett., 1983, 357.

29) 中野惠文, 倉本一弘, 河嶌拓治: 日本化学会誌, $1981,91$.

30) S. Nakano, M. Sakai, M. Tanaka, T. Kawashima: Chem. Lett., 1979, 473.

31) S. Nakano, H. Hayashi, T. Kawashima: Anal. Sci., 9, 695 (1993).

32) S. Nakano, H. Ihara, M. Tanaka, T. Kawashima: Mikrochim. Acta, 1985 I, 455.

33) S. Nakano, M. Tanaka, M. Fushihara, T. Kawashima: Mikrochim. Acta, 1983 I, 457.

34) S. Nakano, K. Nakaso, K. Noguchi, T. Kawashima: 
Talanta, 44, 765 (1997).

35) S. Ohno, N. Teshima, T. Watanabe, H. Itabashi, S. Nakano, T. Kawashima: Analyst, 121, 1515 (1996).

36) 佐藤敬一, 岩村直美, 手嶋紀雄, 中野惠文, 河 嶌拓治: J. Flow Injection Anal., 10, 245 (1993).

37) S. Nakano, A. Ohta, T. Kawashima: Mikrochim. Acta, 1985 II, 273.

38）河嶌拓治，畠山直子，鎌田政明，中野惠文：日 本化学会誌, 1981, 84.

39) Y. Miyata, T. Hirano, S. Nakano, T. Kawashima: Anal. Sci., 7, 97 (1991).

40) 妹尾 学, 木瀬秀夫訳: “分子会合体とその触媒
作用”, (1978), (講談社)；J. H. Fendler, E. J. Fendler, "Catalysis in Micellar and Macromolecular Systems", (1975), (Academic Press, New York).

41) D. Perez-Bendito, S. Rubio: Trends Anal. Chem., 12, 9 (1993).

42) M. L. Lunar, S. Rubio, D. Perez-Bendito: Talanta, 39, 1163 (1992).

43) 百瀬 勉: “有機定性分析”, 第 4 版, (1978), (廣川 書店).

44）小橋一彌，大倉洋甫：ぶんせき (Bunseki), 1980, 710.

45）上野清一, 石崎睦雄：日本化学会誌, 1979, 217.

\section{要旨}

本論文は，有機化合物の酸化還元反応における金属イオンの接触作用を利用した分析法を記述した. ここで扱った反応系は，（1）過酸化水素存在下での $N$-フェニル-p-フェニレンジアミン（PPDA）と $N, N$ ジメチルアニリン（DMA）の酸化カップリング反応，(2) PPDAの過酸化水素による酸化反応，（3）過 酸化水素存在下での 3-メチル-2-ベンゾチアゾリノンヒドラゾンとDMA の酸化カップリング反応，(4) 臭素酸塩存在下での 4-アミノアンチピリンとDMA の酸化カップリング反応である. 活性化作用を示す 配位子あるいは界面活性剂の共存は，分析の感度を飛躍的に上昇させることができた．以上の反応系を 用いた吸光度測定に基づく接触分析法（バッチ法及びフローインジェクション法）により $10^{-11} \sim 10^{-7}$ $\mathrm{M}$ の $\mathrm{Cu}(\mathrm{II}), \mathrm{Co}(\mathrm{II}), \mathrm{Fe}(\mathrm{II}, \mathrm{III}), \mathrm{Mn}(\mathrm{II}), \mathrm{Cr}(\mathrm{III})$ 及び $\mathrm{V}(\mathrm{IV}, \mathrm{V})$ を定量でき, 又実試料の分析に応用し た結果を示した. 